\title{
ИстОРИя
}

DOI: $10.17805 / g g z .2017 .3 .4$

\section{Экологические аспекты жизни древних греков}

\author{
Е. В. ГАВРИЛОВА, Л. И. КОЛЕСНИЧЕНКО \\ МОСКОВСКИЙ ГУМАНИТАРНЫЙ УНИВЕРСИТЕТ
}

В статье рассматриваются аспекты взаимодействия древних греков с окружающей средой, особенности их мифологического восприятия и трактовки природы и ландшафтов, а также некоторые экологические причины, обусловившие направления и способы освоения новых территорий.

Ключевые слова: ареал, арете, виадук, «греческая триада», калокагатия, климат, колонизация, ландшафт, мифотворчество, экология

\section{Ecological aspects of life of the ancient Greeks}

\author{
E. V. GaVRilova, L. I. KOLESNICHENKO \\ MOSCOW UNIVERSITY FOR THE HUMANITIES
}

The article examines aspects of interaction of the ancient Greeks with the environment, especially their mythological perception and interpretations of nature and landscapes, as well as some environmental factors affecting the direction and methods of development of new territories.

Keywords: areal; arete; the viaduct; the "Greek triad"; kalokagathia; climate; colonization; landscape; mythology; ecology

Ученые-климатологи связывают развитие и упадок крупнейших цивилизаций мира с изменениями климата. Его резкие или постепенные смены, происходившие в глобальных масштабах, отражались на условиях существования всех живых существ и, в частности, человека. Примерно 17000 лет до н. э. закончился ледниковый период. Солнечное излучение усилилось и наступил период «глобальной весны». В течение нескольких тысяч лет Земля прогрелась, природный хаос окончился, климат стабилизировался и далее менялся незначительно, вплоть до нашего времени. Постоянная температура вызвала таяние ледников, активный процесс испарения, способствовавший образованию муссонов - выпадению регулярных дождей, которые ускорили вегетацию растений. Почвы становились пригодными для возделывания, эволюционировали виды животных и растений. Биосфера процветала.

С периода стабилизации устойчивых климатических условий можно говорить о начале культурной экспансии человечества на планете. Аюди расселялись по плодородным землям, оседали и развивали свои новые умения и ремесла. Возделывались злаки, овощи, производились новые продукты, улучшавшие рацион питания человека. Появлялись новые профессии. Аюди теперь могли заниматься ремеслами, согласно не только потребностям, но и способностям. Таким образом, развитие сельского хозяйства дало большой толчок к глобальным переменам в становлении обществ.

Однако человечество ждала очередная глобальная катастрофа, которую многие культуры мира описывают как вселенский потоп. В результате активного таяния ледников, уровень мирового океана поднялся на 120 метров, что привело к затоплению 
плодородных земель и общему изменению очертаний материков. Примерно в тот же период, около 7000 лет до н. э., по мнению ученых, произошло некоторое изменение наклона земной оси. Это вызвало перемену климата во многих областях планеты на сухой и холодный. Прекратилось образование муссонов, что повлекло наступление пустынь на всех континентах. Сахара из плодородной долины превратилась в безжизненное пространство. Человечеству пришлось вновь мигрировать в поисках подходящих для жизни земель.

В географическом пространстве между 20 и 40 градусами северной широты образовалась устойчивая климатическая зона, включившая в себя регионы Северной Африки, Персии, Месопотамии, Индии, Китая, Мексики и Средиземноморья, где сформировались и стали одновременно развиваться величайшие мировые цивилизации. Обилие пищи и воды обеспечили долгий период стабильности, что способствовало процветанию новых империй и формированию их культур. Человек стал на путь раскрытия всех своих способностей и талантов. Климат оказал несомненное влияние на дальнейшее развитие человечества.

Одно из самых значительных воздействий на развитие Европы и современного нам мира, оказала древнегреческая цивилизация. Природная среда, в которой развивалась и процветала эта культура, влияла не только на социально-общественное устройство греческого общества, но и на мировоззрение этого народа. Общество не мыслится вне культурного пространства, которое включает в себя религию. Именно религия этноса, тесно сплетенная с климатическими условиями и природными ландшафтами окружающей среды, создала своеобразие каждой цивилизации, в том числе и древнегреческой. Поэтизация природы, в меньшей степени ее обожествление, способствовала развитию мифотворчества, связанного с конкретными географическими зонами, что обусловило вектор культурной направленности этой страны. Аревняя Греция не была единой политической и экономической общностью. Она представляла собой конгломерат городов-государств, полисов, достаточно обособленных в условиях своей географической среды, их «рубежи чаще всего определялись природными границами» (История культуры повседневности, 2017: 171). Но все же Греция была цельной в своей культуре, которую объединяло прежде всего мифологическое пространство, «политеизм (представление о всеобщей одушевленности природы), общегреческие святилища и празднества» (там же: 171). Это давало чувство общности и принадлежности к единому народу, хотя этнически греческое население было разнообразным.

Территория Аревней Греции была довольно обширна. Греческие поселения занимали южную материковую часть Балканского полуострова, полуостров Пелопонес, многочисленные острова Эгейского и Средиземного моря, а также западное побережье Малой Азии (современной Турции). Столь большая разбросанность поселений диктовала особые экономические отношения между полисами, способствовала развитию мореплавания. Море служило объединяющим фактором цивилизации. А. Боннар, швейцарский филолог-эллинист, в своем труде «Греческая цивилизация» отмечает значение моря для древних греков: «Горы защищают и разъединяют, море же объединяет...Море омывало всю страну и глубоко вдавалось в сушу. Аишь очень немногие полисы, только самые отдаленные, не имели выхода к морскому побережью... Не было ни одного греческого города-государства, откуда бы нельзя было видеть, поднявшись на какую-нибудь возвышенность, сверкающую на горизонте морскую даль» (Боннар, 1994: 40). Цандшафты и климат древнегреческого мира не претерпели особых изменений до нашего времени, что дает нам возможность составить относитель- 
но полное представление об экологии этого региона в давние времена. «Климат Аревней Греции мало отличался от нынешнего. Среднегодовая температура не претерпела изменений с античных времен. Она колеблется от 16 градусов $C$ в Фесалии, где климат ближе континентальному, до 19 градусов $C$ на Кикладах. В Афинах и Спарте температура как раз средняя: 17,7 градусов $C$. Атмосферные осадки редки, в западной Греции их выпадает больше, чем в восточной. Недостаточная влажность делает воздух ясным и прозрачным...», - пишет К. Куманецкий (Куманецкий, 1990: 12). И далее: «Аревнегреческий ландшафт был немного иным, чем сегодня, ибо голые в настоящее время скалы Пелиона, Парнаса, Киферона и Геликона были тогда покрыты лесами» (там же). Это были непроходимые заросли, в которых произрастали дубы, кипарисы, ели, сосны, каштаны, дикий орех. Там водились медведи, волки, кабаны и даже львы.

Экологическая картина Греции имеет следующие черты: «...Греция служит типичным примером контрастов геологии, климата, даже парадоксов, присущих Средиземноморскому региону... Контрасты между...скудностью и изобилием, доминирования человека над природой, но и природы над человеком, больше всего заметны в Греции, чем в какой-либо другой стране...Геологическое продолжение балканского полуострова - это особый мир... Неестественно яркий и чистый свет рассеивается над горами и отражается на побережьях и островах. Чистый и свежий воздух наполнен ароматом неисчислимых диких цветов» (Греция...1993: 4). Большую часть материковой Греции (80 \% территории) занимают горы, но «между головокружительными, стремительно возвышающимися горами протягиваются зеленые долины, украшенные хрустальными озерами и голубыми лагунами моря» (там же: 4).

Эгейское море, которое полно островов, очень удобно для мореплавания, и это активно использовали греки. Острова для них были мостом, соединявшим Грецию с берегами Азии. Расстояния между самыми отдаленными островами не превышает 60 км, поэтому мореходство было достаточно безопасным. Морские путешествия осуществлялись сезонно: с весны до осени. Зимой навигация останавливалась, так как в это время начинались ветры и шторма. Аля мореплавания греки использовали только спокойные периоды. По этой же причине они не любили Ионическое и Адриатическое моря, которые были достаточно бурными. Потому все их путешествия, а, следовательно, и изыскания, были устремлены на восток. Из этого можно сделать вывод, что экологические условия диктовали грекам направление колонизации земель.

Благодаря мореплаванию греки приобрели широкие знания и значительные богатства. Путешествие по суше было проблемным в связи с отсутствием хороших дорог, а морское путешествие в те времена стоило дешево. В основном сухопутные дороги вели к святилищам и большей частью использовались паломниками. Море это другое дело. В греческом языке одно из значений этого слова - путь или мост, что определяет возможность связи с другим миром. Вот как пишет об этом А. Боннар: «Греческое море ...это путь для ознакомления с другими народами, для путешествия в страны великих произведений искусства и дивных изобретений, в страны, где обширные равнины покрыты густой пшеницей, а недра земли таят золото» (Боннар, 1994: 41). Исследователь отмечает, что с VII в. до н. э. почти все крупные греческие города имели свои владения за морем. Классической стала фраза Боннара: «Море цивилизовало греков» (там же).

Рассуждая о значении морской стихии в жизни греков, невозможно обойти вниманием великолепный памятник древнегреческой литературы - «Одиссею» Гомера. Недаром в наше время само слово «одиссея» означает «странствия», «богатые при- 
ключениями скитания» (Словарь... 1964: 449). А. Боннар пишет: «В лице Одиссея она (поэма) устремляет целый народ, отважный и любознательный, на завоевание необъятных морских просторов. Спустя несколько поколений после "Одиссеи” Средиземное море, от востока до крайнего запада, станет греческим озером, все главные дороги которого отмечены и освоены» (Боннар,1994: 91). Поэма вдохновляла возвышенные греческие души, исполненные прекрасной арете (греческий термин, обозначавший добродетель, совершенство, достоинство), настраивала их на поиски и открытия новых земель во благо своего полиса, своего народа. В поэме Гомера, которого считают собирательным образом певца-аэда, Одиссей олицетворяет собой весь греческий народ-мореплаватель, устремленный к покорению новых земель. «...Эти рассказы, которые поэт "Одиссеи" превратил в чудесные повести, свидетельствуют, что для греков гомеровской эпохи море, хотя и было преисполнено опасностей, имело, однако, и много привлекательных сторон...В легенде об Одиссее проявляется не только стремление к наживе, но и свойственная греческому народу беспредельная любознательность в отношении мира и его чудес» (там же: 87 ).

Образ Одиссея нельзя рассматривать как конкретную личность, хотя, возможно, что когда-то Итакой правил царь с таким именем. Характерно, что именно царь Итаки, острова, лежащего к западу от материковой Греции, стал символом бесстрашного и удачливого мореплавателя. Ионическое море, соединенное с Адриатикой, было пугающим для большинства его покорителей из-за своей непредсказуемости. Скалистые берега, мощные течения, часто меняющие свои направления, внезапные бури все это способствовало возникновению благоговейного трепета у путешественников. Гомер описывает удивительно точно географические объекты, которые упоминает в «Одиссее». Вот пример описания мыса Малея, который круто спускается к морю своими скалистыми берегами на юго-восточной оконечности Пелопонеса. При обходе вокруг него у древних мореплавателей возникали большие трудности из-за сильных и переменчивых ветров:

Но когда на своих кораблях крутобоких опять он

В темное море пошел и высокого мыса Малеи

Быстро достиг - повсеместно гремящий Кронион, замыслив

Гибель, нагнал на него многошумное ветра дыханье,

Поднял могучие, тяжкие, гороогромные волны.

(Одиссея, III, 285-290)

Гомер дает полную карту морских путешествий, рассказывает о географическом и этническом своеобразии того или иного берега, той или иной земли:

ВАруг корабли разлучив, половину их бросил он к Криту,

Где обитают кидоны у светлых потоков Ярдана. ${ }^{1}$

Виден там гладкий утес, восходящий над влагой соленой,

В темное море вдвигаясь на крайних пределах Гортины; ${ }^{2}$

Там, где великие волны на западный берег у Феста ${ }^{3}$

Нот $^{4}$ нагоняет и малый утес их дробит, отшибая,

Те корабли очутились; проворством спаслися от смерти

Июди; суда ж их погибли, разбившись об острые камни

Пять кораблей темноносых, похищенных бурей,

Ветер могучий и волны ко брегу Египта примчали.

(Одиссея, III, 290-300) 
Уже только из этого небольшого отрывка можно представить, насколько обширным был ареал мореплавания греческих кораблей. Гомеровкие герои, а в их лице и вообще древние греки, прекрасно знали особенности навигации между островами Эгейского моря:
Позже отправился в путь Менелай златовласый: в Аесбосе
Нас он нагнал, нерешимых, какую избрать нам дорогу:
Выше ль скалами обильного Хиоса путь свой на Псиру
Править, ее оставляя по левую руку, иль ниже
Хиоса мимо открытого воющим ветрам Миманта?

(Одиссея, III, 165-175)

Греция - страна тысячи островов, каждый из которых обладает разнообразием природы, неповторимостью ландшафтов и морских акваторий. Самый большой и значимый среди них - остров Крит. Гомер наградил остров такими эпитетами: «широкоравнинный», «пространный» (Одиссея, XVII, 52; Илиада, XIII, 450).

О многонаселенности острова аэд пел так:

Критян же Идоменей предводил, знаменитый копейщик;

В Кносе живущих мужей, в укрепленной стенами Гортине,

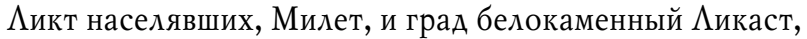

Ритий обширный и Фест, многолюдные, славные грады,

И других, населяющих Крита стоградного земли...

(Илиада, II, 645)

Вокруг Крита разбросано множество мелких утесов, скал и островков. Большинство из них связано с греческой мифологией. Из нее мы узнали, что на этом острове, в тайной пещере, богиня Рея прятала младенца Зевса от его кровожадного отца Кроноса. Аиктийская пещера, упоминающаяся в мифе, расположена неподалеку от деревеньки Псиро и очень похожа на описанную в первых легендах. «Благодаря уникальным природным условиям и очень красивой форме каменных образований, она оставляет непередаваемые впечатления, вне зависимости от того, как вы относитесь к греческим богам, героям и легендам вообще» (Все о Греции. // Anygreece.com).

На Крите есть уникальный горный ландшафт это гора Юкта (по другой транскрипции - Юхтас), которая является географическим центром, связанным с Зевсом. «Юкта горный хребет, тянущийся с юга на север в направлении Кносса, высотой до 2070 футов» (Иосев,1996: фрагм. 128). Эта священная гора, напоминающая профиль бородатого лица Зевса, стала символом острова.

Великолепной достопримечательностью Крита по праву считается дворец в Кноссосе. Помимо прекраснейших фресок минойского периода, которые дают представление о радостной и природолюбивой культуре древних критян, мы узнаем и об экологических достижениях этой цивилизации. Место для дворца выбиралось с учетом выгодного положения относительно моря и было специально подготовлено для строительства: холм, на котором возводили дворец, был срезан с восточной стороны. «Вокруг дворца на территории 750 тыс. кв. м располагался город ... Он пересекался каменными дорогами... Системы водоснабжения и канализации были обширными. Первая система состояла из глиняных труб, доставлявших воду в город и во дворец из соседних родников. Канализационная система состояла из больших построенных водопроводов» (Тзоракис, 2008: 23,27). Ао наших дней сохранился виадук, который де- 
монстрирует очень высокий уровень технических сооружений минойцев. «Руины виадука видны с обеих сторон речки Влихья. Сохранилось четыре огромных основания, имеющие до восьми рядов камней. Эти основания образовывали арочные отверстия. Под ними свободно текла речка, а на них опиралась покрытая камнями дорога для повозок» (там же: 107). Этот виадук, наряду с дворцом, является одним из самых грандиозных памятников Кносса.

Остров Эвбея (современное название Эвия) - еще один интересный эколого-географический объект. Это второй по величине, после Крита, греческий остров. Он расположен недалеко от материковой части Центральной Греции и соединен с ней старинным, но все еще действующим, мостом. Поэтому Эвбею считают естественным продолжением материка, от которого остров отделен множеством нешироких проливов. Самое узкое место составляет всего 38 метров. Вот как упоминает остров Гомер:

Он повелел, чтоб, разрезавши море по самой средине,
Шли мы к Эвбее для скорого близкой беды избежанья;
Ветер попутный, свистя, зашумел, и, рыбообильный
Путь совершая легко, корабли до Гереста5 достигли...

(Одиссея, III, 165-175)

Уникальной достопримечательностью острова является пролив Эврипа. Аревние мореплаватели опасались этого пролива. Ааже в наше время судоходство там осуществляется только ночью в определенные часы. Скорость течения в проливе очень велика - до 8 миль в час (почти 13 км в час). При этом направление водного потока меняется каждые 6 часов, образуя временные стоячие волны. Полностью течение останавливается на некоторое время только ночью. Современные ученые не могут до конца объяснить это природное явление. Существует легенда, что Аристотель, не сумев отгадать загадку этого явления, покончил с жизнь в водах Эврипа.

Остров Эвбея сочетает в себе множество природных богатств: великолепные леса, покрывающие скалистые склоны гор, плодородные долины, огромные пустынные пляжи, горные ущелья, горячие источники и чистейшие речки. Здесь, уже в конце VIII в. до н. э., возникло могущественное поселение Эретрия. В поэме «Теогония» Гесиод упоминает о богатых урожаях винограда на Эвбее, а вино из этих мест высоко ценилось на Востоке. Изображения на чашах и кратерах, хранящихся в эретрийском музее, рассказывают о том, что на острове разводили лошадей, так как прекрасные отлогие берега «длинного острова», как называли его древние греки, были пригодны для коневодства.

В музее Эретрии хранятся миллионы глиняных осколков с письменами. Среди предметов, найденных здесь, многие указывают на происхождение из Египта или с Ближнего Востока. Это доказывает, что эвбейцы активно общались с другими народами. Через Кикладские острова они легко достигали побережья современной Турции и осваивали новые земли. Есть мнение, что именно эвбейцы заимствовали греческий алфавит и письмо у финикийцев, которые использовали только согласные буквы. Греки же добавили гласные буквы и этим положили начало современному европейскому алфавиту (Fox, 2008).

В странствиях по турецкому побережью эвбейцы находили идеи для создания мифов о происхождении богов. Профессор Оксфорда Р. $\Lambda$. Фокс считает, что основанием греческих мифов были хеттские сказания о происхождении мира. Великая хеттская цивилизация погибла примерно в XII в. до н. э. Эвбейцы находили следы этой 
культуры и адаптировали ее в своих «муфоях», т. е. рассказах о богах. У горы Кассиус они основали поселение Альмина. Гора являлась священным местом для хеттов и, конечно, была окутана многочисленными легендами, которые слышали и греки. Вершина горы часто закрыта облаками, и над ней регулярно случаются грозы, сопровождающиеся мощными раскатами грома и страшными молниями. Именно на этой горе произошла первая битва Зевса с ужасным змеем Тифоном. Он одолел Зевса и забрал его сухожилия, спрятав их в тайной пещере - Арима, которая сейчас доступна туристам. Вторая, победоносная, схватка Зевса с Тифоном произошла в Киликии (современная Турция). Там существует разлом, который является местом, где, по легенде, Зевс бил чудовище головой о скалы, которые обагрились кровью Тифона. Миф стал для греков убедительным объяснением появления красных пятен и разводов на желтых скалах ущелья. Это необычное место можно увидеть и сейчас (Ibid.). После победы над Тифоном Зевс навалил на его поверженное тело огромную гору. Это вулкан Этна, который хоть и считается в наше время потухшим, все же дымится, поражая воображение выжженным фантастическим пейзажем. Этна изрыгает ядовитые пары и огненную лаву, когда Тифон пытается освободиться из своей темницы.

Адаптируя необычность природных ландшафтов и экологических явлений под свои мифы, греки осваивали новые территории. Природа давала древним грекам идеи для определения мест мифологических событий. Она как бы являла миру свидетельства, подтверждающие мифы. Это был процесс познания реального мира через мифотворчество. Так греки понимали и объясняли те или иные природные и ландшафтные особенности. «И, хотя, мифы не имеют ничего общего с реальностью, но они отражают реальность», - говорит профессор Робин $\Lambda$ ейн Фокс (Ibid).

Интересы древних греков простирались далеко за пределы эгейского бассейна. Мы знаем, что уже в те далекие времена, греки заходили в Черное море (Понт Эвксинский) и основывали там колонии. Об этом повествует всем известный миф о Золотом Руне. «Освоив южное побережье Черного моря, греки стали проникать в Восточное Причерноморье, главным образом в Колхиду. Они появились в этом регионе в середине - второй половине VI века до н. э.», утверждает исследователь темы С. Ю. Сапрыкин (Античный ...2010: 80). По его словам, греческие поселения в Колхиде были «торговыми факториями и колониями». Ученый указывает на ряд «спорных» версий, по которым они (колонии), «за единичными исключениями, не сумели развиться в полноценные города-государства полисного типа» (там же: 80, 81). Одной из причин приводится экологическая проблема: «из-за специфических природных условий в Колхиде, прежде всего климата и заболоченности побережья, они были слабыми, что привело к преждевременному прекращению их функционирования» (там же: 80,81). Из всего сказанного, можно сделать вывод, что экологические проблемы были не только знакомы древним грекам, но и оказывали влияние на их планы по колонизации новых земель.

Как пишет Пол Картледж, британский историк античности, «основанию каждого поселения сопутствовали разнообразные факторы, имевшие как общий, так и индивидуальный характер. Однако вне зависимости от места при этом неизменно преследовались две цели: во-первых, требовалось сырье, а во-вторых, - земля, на которой можно было бы поселиться и которую можно было бы обрабатывать» (Картледж, 2014: 90). В Аревней Греции производили, как правило, три основных продукта. Это так называемая «греческая триада». Она состояла из зерна, вина и оливкового масла. Зерно - это «преимущественно ячмень, поскольку он весьма засухоустойчив, разные сорта пшеницы и просо...» (там же: 36). Еще выращивали кориандр и шафран. «Зем- 
леделие в большинстве районов Греции требует больших усилий; часто бывает необходимым искусственное орошение ... многие реки не только мелки, но летом вовсе пересыхают» (История Аревней Греции, 1972: 8). По этой причине греки всегда использовали для возделывания любой участок земли, разбивая небольшие сады и огороды, проводя ирригационные работы. Аесные массивы часто вырубались под земледелие или под постройки, поэтому сегодняшняя Греция осталась без лесов.

Аругим важным видом сельскохозяйственной деятельности было скотоводство, которое составляло неотъемлемую часть греческого натурального хозяйства. Оно основывалось на овцеводстве для получения шерсти и козоводстве, которое давало молоко и легкие сыры. К тому же, в континентальной Греции местность гористая и козы были самым неприхотливым и надежным видом для разведения. Это также наносило ущерб природе, поскольку стада коз и других копытных уничтожали леса, объедая молодые побеги деревьев и кустарников. Количество голов скота определяло богатство и престиж семьи, поэтому можно представить насколько мощный урон наносился экологии страны.

Историк Фукидид описывал природу Аттики, как скудную по своим почвам и плохо пригодную для земледелия (Фукидид, 2012). «В целом древнегреческую природу нельзя назвать щедрой и милостивой к человеку», - пишет доктор исторических наук И. Суриков (Суриков, 2005: 19). Слабые почвы не давали возможности для успешного хлебопашества. Поэтому большее внимание уделялось на таких землях выращиванию ячменя, олив и винограда. Продукты, производимые в Аттике, а именно: вино, оливковое масло и гиметтский мед, славились далеко за ее пределами. Однако каменистая почва региона обладала огромными богатствами - запасами сырья: свинца, меди, мрамора и глины. Особенно богатыми были месторождения серебра в Аттике («земле афинян»). Это способствовало развитию морской торговли в Афинах, которые постепенно превратились в крупнейший торгово-ремесленный центр Греции.

Близость к морю (всего в восьми километрах от берега) способствовала активной миграции населения из разных стран и греческих полисов в Афины. Город наполнялся бесконечным количеством людей, искавших здесь удобной и выгодной жизни. Вследствие обилия иноземцев, городское управление вынуждено было принять ряд законов, ограничивающих получение афинского гражданства, чтобы сохранить целостностное и гармоничное лицо своего полиса, который и без того состоял из множества демов (около 140 деревень), расположенных как в городской, так и в сельской местности.

Соблюдение ландшафтных особенностей при строительстве было главной чертой греческого менталитета, который всегда искал упорядоченности, завершенности и целостности внешнего мира с личностным самовосприятием человека. Это было проявлением принципа калокагатии6, служившим основной идеей греческого идеала мироздания. Поэтому все греческие полисы устраивались по определенным законам. Главным местом в любом греческом полисе была агора, или рыночная площадь. Она располагалась у подножия холма. На вершине холма всегда строился акрополь для почитания «бога-покровителя» города. По склонам холма спускались административные и общественные здания, образуя естественный амфитеатр. Вся архитектура Аревней Греции «ориентирована на человеческое восприятие», «она не подавляет, хорошо вписана в окружающий ландшафт» (История культуры повседневности, 2017: 192). Специалисты отмечают, что великолепные памятники древнегреческой архитектуры впечатляют не своими размерами, а гармонией и совершенством форм и пропор- 
ций. Это было материальным воплощением идеи «победы светлого культурного начала над хаотическими силами природы» (Аурье, 1993).

Принципом калокагатии руководствовались все свободнорожденные граждане любого полиса, стараясь следовать ему в различных аспектах своей жизни, в том числе, и в обустройстве частных домов. Их жилища строились с учетом климатических особенностей жаркого региона и фактически представляли собой оптимальный тип средиземноморского дома. Аома были скромными и неприметными. Обычно они строились на прочном «каменном фундаменте, стены были сложены из сырцового кирпича, покрыты штукатуркой и окрашены. Крыша была из глиняной черепицы...» (История культуры повседневности, 2017: 179). Аом выстраивался вокруг внутреннего дворика, «южная часть дома была одноэтажной, а северная - двухэтажной, что обеспечивало мягкий микроклимат в помещении» (там же: 179). Отсутствие окон на первом этаже помогало сохранять прохладу в жилище. Замкнутость и внутренняя аскетичность частных по-строек свидетельствовала об особом понимании эллинами своего места в природном мире, о желании не нарушать гармонию и величие окружающего их естественного пространства.

Греки хорошо осознавали взаимное влияние человека и среды, создавая философские и медицинские теории о единстве природы и всего живого в ней. Трактат Гиппократа «О воздухах, местностях и водах» можно назвать одним из первых экологических трудов, так как в нем ученый указывал на тесную зависимость живого существа от среды обитания. «Человек (как и все живое) оказывался настолько связанным с местностью, почвой, водными источниками, что климатические особенности определяли не только недуги, но и черты характера», - пишет в исследовании о парадоксографии Н. А. Позднякова (Чудеса и оракулы... 2007: 155). Она отмечает, что «ранние парадоксографы в основном пытались систематизировать свидетельства о явлениях природы. ... Особенности различных местностей и произрастающих там растений, населяющие эти местности животные и другие естественно-научные парадоксы - также наиболее частые темы их произведений. ... Эллины составляли описания неведомых земель, необычных сооружений, растений, камней и других диковинных... явлений» (там же: 155-156).

Природа, будучи основой человеческого существования, рассматривалась древними греками как часть мирового космоса, который гармонизирует человеческую личность. Эпиктет - философ, бывший рабом в Риме, выразил суть древнегреческого мировосприятия такими словами: «Если человек имеет возможность рассуждать и может созерцать солнце, луну и звезды и наслаждаться дарами земли и моря - он не одинок и не беспомощен» (Мудрость Аревней Греции и Рима, 2013: 163). Его слова определяют мысль о ценностях греческого сознания и миропонимания, которые неукоснительно соблюдались эллинами в любых видах и формах взаимодействия с миром природы. Некоторые из них можно выделить как экологические аспекты. Это обожествление и защита сакральных и заповедных мест; это нейтральное, опосредованное взаимодействие, например с морем; и это беспощадное переустройство территорий в зависимости от потребностей и возможностей конкретного полиса. Об этом же писал знаменитый антиковед Ф. Ф. Зелинский: «Мать-земля, наделившая свою любимицу Элладу столькими драгоценными дарами, не избаловала ее плодородием: ее народ должен был добывать свое скудное пропитание таким трудом, о котором понятия не имеют жители благодатных равнин. Приходилось строить каменные террасы по склонам гор, чтобы спасти от зимнего размыва плодородный слой, которого никто, 
бывший в тех краях, не назовет «черноземом»; приходилось в удобных местах рыть бассейны в каменистой почве, чтобы сберечь драгоценную небесную влагу на бездождные месяцы; приходилось посредством каналов отводить струи рек, чтобы обеспечить полям необходимое орошение...Труд человека довольно-таки основательно нарушал божественную жизнь Матери...» (Зелинский, 2014: 45).

Аревние греки понимали, что вынуждены оказывать влияние на окружающий их мир. Поэтому они населили его богами и наполнили мифологическими событиями, которые стали некими законами и оберегами Матери-природы от непомерного человеческого эгоизма. Особенности восприятия окружающего космомира, в том числе ландшафтов и климата, позволили древним грекам найти способы тонкого взаимодействия внешнего и внутреннего состояний и проявлений своей жизни по отношению к силам природы. Влияние экологических и географических факторов на греческую культуру, определило направления и способы освоения новых территорий, а также обусловило ее гармоничность и созвучность лучшим природным образцам.

\section{ПРИМЕЧАНИЯ}

${ }^{1}$ Речь идет о племени кидонов (предках иудеев), которые обитали на Крите и при позднем переселении в Иивию перенесли с собой и название Ярдан, т. е. Иордан .

2 Гортина - один из древнейших городов Крита (с 5 -го тысячелетия до н. э.).

3 Фест - полис-дворец, погибший в 1456 г. до н. э. Находился рядом с Гортиной.

${ }^{4}$ Нот (notoc) - южный ветер.

5 Герест - мыс на о. Эвбея, посвящен Посейдону.

${ }^{6}$ Калокагатия - красота и совершенство внешнего (физического) и внутреннего ( Ауховного).

\section{ИСТОЧНИКИ}

Аристотель (1940) О возникновении животных. М.- $\Lambda$. : Изд-во АН СССР. 249 с.

Гераклит Эфесский (1910) Фрагменты. М. : Мусагетъ. 96 с.

Гесиод (2016) Работы и дни. Теогония. Щит Геракла. М. : $\Lambda$ ЕНАНА. 284 с.

Гомер (1993) Илиада. М. : Аюна. 432 с.

Гомер (1993) Одиссея. М. : Аюна. 320 с.

Платон (2016) Полн. собр. соч. : в 1 т. М. : Альфа-книга. 1312 с.

Страбон (1994) География. М. : Аадомир. 944 с.

ФукидиА (2012) История. М. : Академический проект. 576 с.

\section{СПИСОК АИТЕРАТУРЫ}

Античная культура (2002): словарь-справочник / сост. В. Н. Яхро. М. : Аабиринт. 352 с.

Античный полис (2010): сб. М. : Общественный Фонд Содействия Образованию и Науке. 240 с. Боннар, А. (1994) Греческая цивилизация: в 2 т. Ростов н/А. : Феникс. Т. 1, 448 с.

Борзова, Е. П. (2001) История мировой культуры. СПб. : Аань. 672 с.

Велишский, Ф. (2000) История цивилизации: Быт и нравы древних греков и римлян. М. : ЭКСМО-Пресс. 704 с.

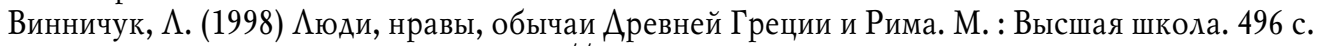

Все о Греции [Электронный ресурс] // Путешествия по Греции интернет-журнал Anygreece.com (C) URL : https://anygreece.com/krit/krt-dostoprime-chatelnosti/chitaem-mifyi-drevney-gretsii.html (дата обращения: 17.05.2017)

Гиро, П. (1995) Частная и общественная жизнь греков. СПб. : Алетейя. 474 с.

Гиро, П. (2002) Быт и нравы Аревних греков. Смоленск : Русич. 624 с.

Аушенко, К. В. (2004) Мысли и изречения древних. М. : Эксмо. 800 с.

Зелинский, Ф. Ф. (1995) История античной культуры. СПб. : Марс. 380 с.

Зелинский, Ф. Ф. (1995) История античных религий : в 4 т. I-III. СПб. : Квадривиум. 864 с.

Греция: История-искусство-фольклор (1993) : сб. статей. Афины : TOUBIS. 160 с. 
История Аревней Греции (1972). М. : Высшая школа. 424 с.

История культуры повседневности (2017) / под ред. В. П. Большакова. М. : Проспект. 496 с. Картледж, П. (2014) История Аревней Греции в 11 городах. М. : АСТ. 285 с.

Касьянов, В.В.(2016) История культуры. М.: Юрайт. 390 с.

Козьякова, М.И. (2016) История. Культура. Повседневность. М. : ООО «Согласие». 512 с.

Куманецкий, К. (1990) История культуры Аревней Греции и Рима: пер. с пол. М. : Высшая школа. 351 с.

Иосев, А. Ф. (1996) Мифология греков и римлян. М. : Мысль. 599 с.

Москвин, А. Г. (2014) Греция. Эллада: от Афин до Пелопонеса. М. : Вече. 288 с.

Мудрость Аревней Греции и Рима (2013). М. : Олма. 304 с.

Словарь иностранных слов (1964). 6-е изд. М. : Сов. Энциклопедия. 784 с.

Суриков, И. Е. (2005) Аревняя Греция: история и культура. М. : АСТ: Астрель. 190 с.

Тзоракис, Г. (2008) Кноссос. Афины : ЕСПЕРОС. 120 с.

Тимофеев, И. В. (2015) Греческие острова. М. : Эксмо. 464 с.

Чудеса и оракулы в эпоху древности и средневековья (2007) / сб. М. : Крафт+; Институт Востоковедения РАН. 400 с.

Fox, R. L. (2008) Travelling Heroes: Greeks and Their Myths in the Epic Age of Homer. London : Allen Lane. 496 p.

\section{SOURCES} Russ.)

Aristotel' (1940) O vozniknovenii zhivotnyh. Moscow-Leningrad, Izd-vo AN SSSR. 249 s. (In

Geraklit Ehfesskij (1910) Fragmenty. Moscow, Musaget. 96 s. (In Russ.)

Gesiod (2016) Raboty i dni. Teogoniya. Shchit Gerakla. Moscow, LENAND. 284 s. (In Russ.) Gomer (1993) Iliada. Moscow, Dyuna. 432 s. (In Russ.)

Gomer (1993) Odisseya. Moscow, Dyuna. 320 s. (In Russ.)

Platon (2016) Poln. sobr. soch. : v 1 t. Moscow, Al'fa-kniga. 1312 s. (In Russ.)

Strabon (1994) Geografiya. Moscow, Ladomir. 944 s. (In Russ.)

Fukidid (2012) Istoriya. Moscow, Akademicheskij proekt. 576 s. (In Russ.)

\section{REFERENCES} Russ.)

Antichnaya kul'tura (2002): slovar'-spravochnik / sost. V. N. Yahro. Moscow, Labirint. 352 s. (In

Antichnyj polis (2010): sb. Moscow, Obshchestvennyj Fond Sodejstviya Obrazovaniyu i Nauke. 240 s. (In Russ.)

Bonnar, A. (1994) Grecheskaya civilizaciya: v 2 t. Rostov n/D. : Feniks. T. 1, 448 s. (In Russ.)

Borzova, E. P. (2001) Istoriya mirovoj kul' tury. Sankt-Peterburg, Lan'. 672 s. (In Russ.)

Velishskij, F. (2000) Istoriya civilizacii: Byt $i$ nravy drevnib grekov $i$ rimlyan. Moscow, EHKSMO-Press. 704 s. (In Russ.)

Vinnichuk, L. (1998) Lyudi, nravy, obychai Drevnej Grecii i Rima. Moscow, Vysshaya shkola. 496 s.(In Russ.)

Vse o Grecii // Puteshestviya po Grecii internet-zhurnal Anygreece.com (C), [online] Avaible at: https://anygreece.com/krit/krt-dostoprime-chatelnosti/chitaem-mifyi-drevney-gretsii.html (access date: 17.05.2017) (In Russ.) Russ.)

Giro, P. (1995) Chastnaya i obshchestvennaya zhizn' grekov. Sankt-Peterburg, Aletejya. 474 s. (In

Giro, P. (2002) Byt i nravy Drevnib grekov. Smolensk, Rusich. 624 s. (In Russ.)

Dushenko, K. V. (2004) Mysli i izrecheniya drevnib. Moscow, Ehksmo. 800 s. (In Russ.)

Zelinskij, F. F. (1995) Istoriya antichnoj kul'tury. Sankt-Peterburg, Mars. 380 s. (In Russ.)

Zelinskij, F. F. (1995) Istoriya antichnyb religij: v 4 t. I-III. Sankt-Peterburg, Kvadrivium. 864 s. (In Russ.) 
Greciya: Istoriya-iskusstvo-fol'klor (1993) : sb. statej. Afiny, TOUBIS. 160 s. (In Russ.)

Istoriya Drevnej Grecii (1972). Moscow, Vysshaya shkola. 424 s. (In Russ.) Russ.)

Istoriya kul'tury povsednevnosti (2017)/ pod red. V. P. Bol'shakova. Moscow, Prospekt. 496 s. (In

Kartledzh, P. (2014) Istoriya Drevnej Grecii v 11 gorodab. Moscow, AST. 285 s. (In Russ.)

Kas'yanov, V.V.(2016) Istoriya kul' tury. Moscow, Yurajt. 390 s. (In Russ.) Russ.)

Koz'yakova, M.I. (2016) Istoriya. Kul'tura. Povsednevnost'. Moscow, OOO «Soglasie». 512 s. (In

Kumaneckij, K. (1990) Istoriya kul'tury Drevnej Grecii i Rima: per. s pol. Moscow, Vysshaya shkola. 351 s. (In Russ.)

Losev, A. F. (1996) Mifologiya grekov i rimlyan. Moscow, Mysl'. 599 s. (In Russ.)

Moskvin, A. G. (2014) Greciya. Ebllada: ot Afin do Peloponesa. Moscow, Veche. 288 s. (In Russ.)

Mudrost' Drevnej Grecii i Rima (2013). Moscow, Olma. 304 s. (In Russ.)

Slovar' inostrannyb slov (1964). 6-e izd. Moscow, Sov. Ehnciklopediya. 784 s. (In Russ.) Russ.)

Surikov, I. E. (2005) Drevnyaya Greciya: istoriya i kul'tura. Moscow, AST: Astrel'. 190 s. (In

Tzorakis, G. (2008) Knossos. Afiny, ESPEROS. 120 s. (In Russ.)

Timofeev, I. V. (2015) Grecheskie ostrova. Moscow, Ehksmo. 464 s. (In Russ.)

Chudesa $i$ orakuly $v$ ebpohu drevnosti $i$ srednevekov'ya (2007) / sb. Moscow, Kraft+; Institut Vostokovedeniya RAN. 400 s. (In Russ.)

Fox, R. L. (2008) Travelling Heroes: Greeks and Their Myths in the Epic Age of Homer. London, Allen Lane. 496 p.

Аата поступления: 20.05.2017 2.

Гаврилова Елена В. - студентка заочного отделения факультета культуры и искусства, Московский гуманитарный университет. Адрес: 111395, Россия, г. Москва, ул. Юности, А. 5. Тел.: +7 (499) 374-61-81. Эл. адрес: livkolesn@yandex.ru

Колесниченко Аариса Ивановна - кандидат исторических наук, доцент кафедры философии, культурологии и политологии, Московский гуманитарный университет. Адрес: 111395, Россия, г. Москва, ул. Юности, д. 5. Тел.: +7 (499) 374-61-81. Эл. адpec: livkolesn@yandex.ru

Gavrilova Elena V., student of the correspondence Department of the faculty of culture and arts, Moscow University for the Humanities. Postal address: 5, Yunosti St., Moscow, Russian Federation 111395. Tel.: +7 (499) 374-61-81. E-mail: livkolesn@yandex.ru

Kolesnichenko Larisa Ivanovna, Candidate of History, Associate Professor, Department of Philosophy, Culturology and Politology, Moscow University for the Humanities. Postal address: 5, Yunosti St., Moscow, Russian Federation 111395. Tel.: +7 (499) 374-61-81. E-mail: livkolesn@yandex.ru

\section{Аля иитирования:}

Гаврилова Е. В., Колесниченко А. И. Экологические аспекты жизни древних греков [Электронный ресурс]// Горизонты гуманитарного знания. 2017, №3. URL: http://journals. mosgu. $\mathrm{ru} / \mathrm{ggz} / \mathrm{article/view/514}$ (дата обращения: дд.мм.гггг.). DOI: 10.17805/ggz.2017.3.4 